\section{Europe avoids moratorium}

\section{Munlch \& Paris}

THE European Parliament in Strasbourg on 25 May narrowly avoided imposing a five-year moratorium on the sale of certain products of genetic engineering. The moratorium, which was defeated by a single vote, would have applied to products of genetic engineering sold in European Community (EC) countries and which were intended for release into the environment.

The Parliament also narrowly rejected a ban on production or release of genetically engineered organisms such as bacteria altered to produce toxins. Eventually, such a ban may be reconsidered by the EC Commission, which is the executive body of the EC.

The Commission had last year asked the Parliament to respond to a set of guidelines for regulating both production and release of genetically engineered organisms. The Parliament advised slightly stricter guidelines than the Commission had suggested.

The moratorium, put forward by a coalition of Social Democrats and Greens led by West German Social Democrat Gerhard Schmid, would have applied only to products and not to scientific work. In the areas of production and laboratory work, the Parliament recommended "licensing" instead of "registration" of experiments with national authorities. The Parliament asked for risk assessment, strict liability in case of accident and public information about planned releases and their risks. Many restrictive amendments were not approved by the Parliament.

Schmid also wanted to forbid the release of any pathogenic organism and to ban any production or release involving a third category of "unacceptable" microorganisms. The current proposal divides organisms into the categories of "high" and "low" risk. Schmid wanted an environmental impact study to be compulsory for all work involving "high-risk" organisms that could lead to products.

The Parliament accepted the Commission's view on the difficult question of how to resolve disputes between EC member states about which releases are acceptable. The Commission recommended that all scientific experiments be carried out under the auspices of individual national governments. Only when products are to be marketed in a country belonging to the EC may another member state protest. If a dispute cannot be settled between the members, it will be submitted to binding arbitration.

"A wise company" would not let it come to this, said one EC official. It would "ensure that the product was generally acceptable before marketing it in the EC".
The Parliament's proposal will now return to the European Commission for discussion and will be debated by the Council of Environment Ministers in Luxembourg on 8 June. General consent is expected, say Schmid and EC officials in Brussels. If approved, the amended bill will be given a second reading by a newly elected European Parliament later in the year.

The European Parliament has provided a forum for left-of-centre views, especially from Green and Social Democratic parties out of power in their home countries. A left-leaning coalition fought for stricter environmental regulation in this last session of Parliament before the European-wide election of a new Parliament on 18 June. Their narrow defeat on the last day of the session reflected "Christian Democrats and British Conservatives" successfully mustering their forces, according to Schmid. The moratorium was defeated by 68 votes to 67 ; the full contingent of 518 members was depleted by election campaigns.

Steven Dickman \& Peter Coles

\section{NUCLEAR POWER}

\section{Wackersdorf finally dies}

\section{Munich}

Construction was halted at 5 p.m. on 31 May at the controversial nuclear fuel reprocessing facility at Wackersdorf at the urging of the West German government. It now seems that the plant, in which DM 2,600 million had already been invested, will never be completed. A minimum of DM 5,000 million is needed to finish construction. Sending nuclear fuel for reprocessing abroad will be significantly less expensive.

The government was taken by surprise by the plans of the West German utility VEBA to reprocess nuclear fuel elements at the French facility at The Hague (see Nature 338, 611; 1989). Now negotiations have begun to reprocess half of West German fuel at the British Nuclear Fuels Limited (BNFL) facility at Sellafield. Even at the bargain price offered by $\mathrm{BNFL}$ - roughly DM 1,300 per kilogram of fuel, as opposed to DM 1,500 offered by the French concern Cogema - the contract could bring as much as DM 310 million per year for 15 years to BNFL. BNFL is wholly owned by the British government.

With the death of Wackersdorf, antinuclear activists are losing interest in the cause. A demonstration in Munich drew only 7,500 people instead of the expected 30,000 . Protest leaders said they would try to redirect the movement against the final storage of nuclear fuel and waste products in West Germany and against the French facility at The Hague. Steven Dickman

\section{Massachusetts set to crush polluters}

\section{Boston}

A NEW 34-member environmental 'strike force' of scientists, lawyers and undercover police officers, equipped with aerial surveillance capabilities, is the Massachusetts answer to increasing industrial pollution. Declaring that polluters have fouled water supplies in more than 100 state districts and created more than 1,000 toxic dumps, state officials, including Governor Michael Dukakis, are backing the toughest pollution counter-offensive ever seen in the United States.

Announcing the new plan, Dukakis justified the strong-arm approach by calling industrial environmental offences "violent crimes". Industrial polluters, he explained, "do violence against neighbourhoods and against the water we drink and the air we breathe".

The state's dismal financial situation

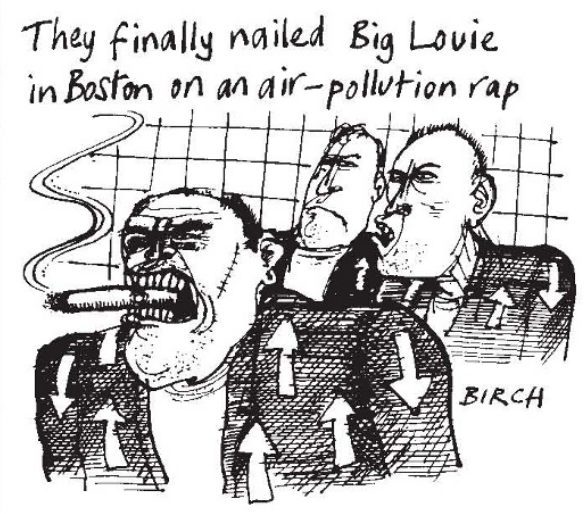

allows no new funds for the programme which will make a start by shuffling personnel and funds from existing agencies. What it lacks in funding, however, the plan seems to make up in support from top state officials who clamoured to endorse it. Massachusetts' Attorney General promised that the new programme "will bulldoze right through the bureaucracy". And the state's secretary for environmental affairs told reporters: "The strike force is the jewel in our environmental enforcement crown".

In addition to the new environmental enforcement team, Dukakis promised legislation later this year to stiffen the state penalties for industrial polluters. But most officials say that the main problem has been lack of enforcement rather than lack of tough laws.

According to Daniel Greenbaum, head of the state department of environmental quality engineering, as many as half of those discharging pollutants into the air and water may be doing so illegally. Of those companies with environmental permits, many routinely get away with violating the terms of the regulations.

Seth Shulman 